„Bohemistyka” 2019, nr 1, ISSN 1642-9893

Tatiana ANIKINA

DOI: 10.14746/bo.2019.1.6

Natalia STACKELBERG

St. Petersburg State University

\section{The image of birds in Czech literature}

Keywords: image, bird, mythologem, symbol

\section{Abstract}

This article is devoted to show the common grounds of Czech and other European literature. Images of birds have an imposing tradition of use in Czech literature. They are characterized by a variety of meanings and history of existence. There are both traditional and everyday folklore images, such as mythologeme of raven for the first one, and geese for the second, which have different semantic workloads. Discussion of the image of birds in the Czech literature is the basement of conclusions about the common ground that brings Czech and European literature together. Moreover, it also gives us more details about Czech national identity, the specifics of its literary schools and movements and the originality of the author's vision of the world.

\section{The foundations}

Images of birds have great history and strong tradition of use in Czech literature. These images have various meaning and history of existence. European topic, national tradition, author's vision of the world and image of bird and also features peculiar to the genre and literary movements can predominate in this image.

Thus, for example, traditional folklore images of Czech fairy tales, usually being mythologems, represent the European topic. Foremost, this is the mythologem of raven or crow, carrying living and dead water.

Ach nězabiže, dobrý človeče, naše mladé, ved' sa ti my chceme všetkým dobrým odslúžitit!“ prosila stará vrána. ,Len vtedy vám mladé vaše pustím, ked' mně doněsietě živej a mítvej vody!“ — „Ej donesieme, donesieme!“ vzkřikli staří jedním hlasem. [...] nesouce každá jednu lahvičku v zobáku (Němcová 2012, p. 11).

\section{Traditional and everyday folklore}

In pre-Christian mythological representations raven has distinct chthonic function (Гypa 1997), carrying out communication with the lower world (Славянские древности... 1995, т. 1, p. 434). According to K. Levi-Strauss, the fact that the raven eats carrion is the reason that the mythologeme is perceived as a mediator between life and death: carrion is already not an animal, but also not a plant food, that is why the raven represents a compromise between carnivorous and herbivorous animals, the juxtaposition of which to each other reflects the antinomy of life and death (Леви-Стросс 2011, p. 234-270). Hence, we have two types of water that the raven brings.

Мертвая вода [...] как бы добивает, превращает [...] в окончательного мертвеца. Это своего рода погребальный обряд, соответствующий обсыпанью землей $[\ldots]$ Только теперь, после окропления мертвой водой [...] живая вода будет действовать (Пропп 1959, p. 282).

The mythologem of raven/crow, along with other methods, introduces Czech literature to the European cultural space, giving it a worthy place, and that becomes more significant if we take the difficult fate of Czech literature into consideration.

Along with mythological images in folklore there are also images of "everyday" character. First of all, this is the image of geese, which is associated with the activities of peasant children - one of the first agricultural work, which was entrusted to young children in peasant families - grazing geese. In the old folk song Nemelem, nemelem, the character asks the female character to remember the distant time when they grazed geese together:

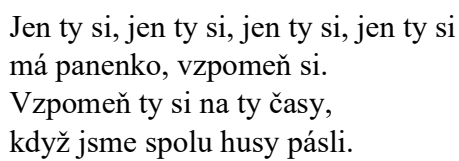

(Nemelem, nemelem) 
Traditional and everyday folklore images differ in their semantic workload. Everyday images were designed to show not the common thing that unites the folklore of the Czechs with the folklore of the peoples of Europe - this was the function of mythological images, but its individuality, distinction. Actually, this individual just turned into a common, as in the case of geese. In many European countries, peasant children began with this work.

The same can be said about the literary topic. The use of common European symbols introduces Czech literature to a number of European literatures, national symbols show its exclusivity. First and foremost, to the literary topic applies, of course, a romantic image a marker of spring and love, the image of the nightingale.

$$
\begin{aligned}
& \text { O lásce šeptal tichý mech; } \\
& \text { květoucí strom lhal lásky žel, } \\
& \text { svou lásku slavík růži pěl, } \\
& \text { rǔžinu jevil vonný vzdech }
\end{aligned}
$$$$
\text { (K. H. Mácha) }
$$

The Czechs have their own image - the image of a dove, which we find in the first lines of the famous romantic poem by K. H. Mácha May (Máj).

$$
\begin{aligned}
& \text { Byl pozdní večer - první máj -- } \\
& \text { večerní máj - byl lásky čas. } \\
& \text { Hrdliččin zval ku lásce hlas, } \\
& \text { kde borový zaváněl háj }
\end{aligned}
$$$$
\text { (K. H. Mácha) }
$$

\section{Birds in literature}

Turning to the images of birds in literary monuments, we can see how Czech writers of the twentieth century continue the national traditions. An example is a poem by Vitězslav Nezvala $A$ sigh (Po$v z d e c h$ ), a kind of elegy, typical for Czech literature, the filling of which are sad thoughts about the time, the irrevocability of the past, regrets about the beauty of what is gone, but, meanwhile, the hope for the future.

$$
\begin{aligned}
& \text { Při řece Rokytně } \\
& \text { se perou bílé husy } \\
& \text { Sám samoutinký jdu si } \\
& \text { Nebe je blankytné } \\
& \text { Ty kraji plný lip } \\
& \text { a bramborových polí } \\
& \text { pročpak mě srce bolí } \\
& \text { Kdysi nám bylo líp } \\
& \text { Pil jsem z tvých okapů } \\
& \text { Ta dobrá jabloň ví to } \\
& \text { Dnes je mi všeho líto } \\
& \text { Sám sebe nechápu } \\
& \text {... Habrové mýtiny } \\
& \text { ty nikdy neuvadnou } \\
& \text { Vrátím se k nim až spadnou } \\
& \text { mně s očí šupiny } \\
& \text { A vykoupám se v nich } \\
& \text { jak husy bílé peří } \\
& \text { jež blýská když se šeří } \\
& \text { jak čistý jarní sníh. }
\end{aligned}
$$

At the beginning of the poem, trying to describe a simple unpretentious landscape of a homeland, the poet recalls the river Rokitna, on one shore of which white geese fight. At the end of the poem, he says that the native nature will allow the yearning, not knowing what his destiny is, lyrical hero "to clean the white feathers, which will shine like pure spring snow at dusk." Surprisingly, Nezval, who paid tribute to modernism, the founder of the vanguard trends of poetry and surrealism, prefers national images to the topic. It seems that this phenomenon has mental nature.

\footnotetext{
${ }^{1}$ Source: https://mujweb.cz/lludvik/nezval/dilo/Pet_prstu.txt [2018-10-02].
} 
Nezval was echoed by another representative of Czech modernism, Antonin Sova. In his famous poem Ponds (Rybniky) from the cycle My homeland ( $Z$ mého kraje) describing the pond and drawing an impressionistic picture of his native nature, he mentions a wild $d u c k$, in greenish feathers of which water drops shimmer with all the colors of the rainbow.

$$
\begin{aligned}
& \text { Ty české rybníky jsou stříbro slité, } \\
& \text { Tu................................... } \\
& \text { Tu sluka steskne v rákosí blíž kraje, } \\
& \text { a kachna vodní s peřím zelenavým, } \\
& \text { jak duhovými barvami když hraje, } \\
& \text { se nese v dálce prachem slunce žhavým } \\
& \text { (A. Sova) }
\end{aligned}
$$

Both examples demonstrate the fact that while drawing pictures of native Czech nature, writers turn to simple "everyday" images, thereby emphasizing the specificity of national literature. It is interesting that the transfer of the author's vision of the native landscape is similar for all poets of that time. Perhaps, in this case the mechanisms peculiar to the literary direction work.

It should be noted that Czech literature is characterized by another feature - the desire to write "for the eye", to draw visual images. Mácha, describing the boat under the white sail, which appeared in the dark waters of the evening lake, resorted to a figurative comparison, comparing it with a white dove flying in the shadow of a black cloud. The image is being enhanced by a picture of a white waterlily blooming in dark water. It creates an expressive image "for the eye", a bright visual picture.

Jak holoubátko sněhobílé

pod černým mračnem přelétá,

lílie vodní zakvétá

nad temné modro; tak se číle -

kde jezero se $\mathrm{v}$ hory níží -

po temných vlnách cosi blíží,

rychle se blíží. Malá chvíle, a již co čápa vážný let,

ne již holoubě či lílie květ,

bílá se plachta větrem houpá.

$$
\text { (K. H. Mácha) }
$$

Describing the city of Leningrad, in the same-named poem, M. Půjmanová, apparently referring to the sunset over the Neva river during the White nights, calls the city "the Nordic bluish-purple swan, Nordic grey swan".

$$
\begin{aligned}
& \text { Ty město krásné, město mé } \\
& \text { s očima měnavýma, } \\
& \text { kdo nezná je, ten utoné, } \\
& \text { severní labuti siná, } \\
& \text { severní šerá labuti } \\
& \text { pod opálovou perutí } \\
& \text { (Půjmanová 1958, p. 206) }
\end{aligned}
$$

Nevertheless, in the Czech poetry of the twentieth century, the swan can be used in the traditional mythological meaning: referring to the beloved, the lyrical hero of the early poem of Nezval calls her "swan, beauty".

$$
\begin{aligned}
& \text { Labutí, } \\
& \text { krásko, } \\
& \text { dvěstě let ubíhá za jediný den, } \\
& \text { zámecká okna ti házejí } \\
& \text { smuteční kytice, } \\
& \text { vodotrysku sen, } \\
& \text { těch lásek úsměv dvorný - } \\
& \text { vspomínám... } \\
& \qquad \text { (V. Nezval 1922) }
\end{aligned}
$$

The hero of the Czech lyrics also becomes a swallow, as a symbol of flight, the desire to spend some time in the beautiful warm Italy. Nezval emphasizes that the fate of a swallow is flight and the fate of the poet is song. 
A jestli viděl jsem co neviděli jiní

tím lépe vlaštovko jež hledáš rodný chlév

Ukázalas mi jih kde máš své hnízdo v skř́íni

Tvým osudem je let mým osudem je zpěv

(V. Nezval)

\section{Conclusion}

Thus, discussion of the image of birds in the Czech literature allows us to draw conclusions about the common ground that brings it together with other European literature, about its national identity, the specifics of its literary schools and movements and the originality of the author's vision of the world.

Translated by Anastasia Korchagina

\section{References}

Гура А. В., 1997, Символика животных в славянской народной традиции, Москва. Online: http://inslav.ru/publication/gura-v-simvolika-zhivotnyhv-slavyanskoy-narodnoy-tradicii-m-1997.

Л е в и - С т р о с с К., 2011, Структурная антропология, Астрель, Москва.

М ел е т и н с к й Е. М., 1979, Палеоазиатский мифологический эпос, Цикл Ворона, Москва.

П р о п п В., 1959, Исторические корни волшебной сказки, Москва.

Славянские древности. Этнолингвистический словарь, 1995, ред. Н. И. Толстой, т. 1, Москва.

Má c h a K. H., Máj. Online: http://babel.mml.ox.ac.uk/naughton/maj.html.

Nemelem - nemelem. Online: https://texty-pisni.eu/lidove-pisne/nemelem-nemelem.

Ne zv a 1 V., 1922, Most. Praha.

Ne z val V., Sbohem a šáteček. Online: http://www.visegradliterature.net/works/ cz/Nezval.

N ě m c o vá B., 2012, O ptáku Ohniváku a mořské panně, Praha.

P ů j m a n o vá M., 1958, Básně, Praha.

S o v a A., Rybniky. Online: http://www.cesky-jazyk.cz/citanka/antonin-sova/rybniky-z-meho-kraje.html. 